\title{
Military Outlay and Economic Growth: The Scenarios of Lake Chad Basin Countries of the Republic of Chad and Nigeria
}

\author{
Innocent.U. Duru ${ }^{1 \star}$ \\ Millicent Adanne Eze ${ }^{2}$ \\ Bartholomew.O.N. Okafor ${ }^{3}$ \\ Abubakar Yusuf ${ }^{4}$ (D) \\ Lawrence.O. Ede $^{5}$ (D) \\ Abubakar Sadiq Saleh ${ }^{6}$ (D)
}

'Department of Economics, Renaissance University Ugbawka, Enugu State, Nigeria.

Email:iudsx@yahoo.com Tel: +234-8154827934

'School of Business, Law and Social Sciences, Abertay University, Dundee, United Kingdom.

Email:ezemillicent@gmail.com Tel:(+44)7459452103

${ }^{s}$ Department of Economics, Nile University of Nigeria, Nigeria.

Email:bartholomerv.okafor@yahoo.com Tel: +234-8035884s78

"National Metallurgical Development Centre (NMDC) Jos, Plateau State, Nigeria.

Email.bbkr_yusuf200o@yahoo.com Tel.+2348179263699

${ }^{5}$ Department of Business Administration, Renaissance University Ugbawka, Enugu State, Nigeria.

Email:edemaclarw@yahoo.com Tel:+2s4-8037469809

${ }^{6}$ Department of Banking and Finance, University of Abuja, Abuja, Nigeria.

Email:abubakar.saleh@nileuniversity.edu.ng.Tel: +234-8055252193

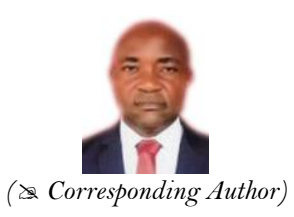

\section{Abstract}

This study examined the relationship between military outlay and economic growth in the Lake Chad Basin countries of Nigeria and the Republic of Chad respectively by testing the causal link between these two principal variables. The data ranges used for Nigeria and Chad were 19812019 and 1983-2019 respectively. The econometric method employed for this study was the Autoregressive Distributed Lag Bounds approach to cointegration. The results revealed that Nigeria's military outlay exerted a positive and insignificant relationship with economic growth. However, the Republic of Chad's military outlay had a positive and significant link with economic growth. The results of the causality test showed that there was no causal relationship between real GDP per capita and military outlay in both Nigeria and the Republic of Chad. These findings for Nigeria and Chad imply that they can pursue the policy objectives of defence and economic growth independently. The study, thus, recommends that the policymakers of the governments of both countries should pursue the policy objectives of defence and economic growth independently. Furthermore, the Economic and Financial Crimes Commission (EFCC) and Independent Corrupt Practices and other Related Offences Commission (ICPC), charged with the responsibility of fighting corruption should rise to the occasion and track down military officials that divert defence funds for individual gains in Nigeria.

Keywords: Military outlay, Economic growth, Cointegration, ARDL, Toda, Yamamoto multivariate causality, Nigeria, Chad. JEL Classification: H59; C32; O49; O55.

Citation | Innocent .U. Duru; Millicent Adanne Eze; Bartholomew .O.N. Okafor; Abubakar Yusuf; Lawrence .O. Ede; Abubakar Sadiq Saleh (2021). Military Outlay and Economic Growth: The Scenarios of Lake Chad Basin Countries of the Republic of Chad and Nigeria. Growth, 8(1): 12-26.

History:

Received: 24 May 2021

Revised: 21 June 2021

Revised. 21 June 202

Accepted: 12 July 2021

Licensed: This work is licensed under a Creative Commons Attribution 3.0 License (c))

Publisher: Asian Online Journal Publishing Group
Acknowledgement: All authors contributed to the conception and design of the study.

Funding: This study received no specific financial support

Competing Interests: The authors declare that they have no conflict of interests.

Transparency: The authors confirm that the manuscript is an honest, accurate, and transparent account of the study was reported; that no vital features of the study have been omitted; and that any discrepancies from the study as planned have been explained.

Ethical: This study follows all ethical practices during writing. 
Contents

1. Introduction

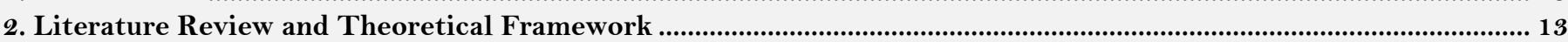

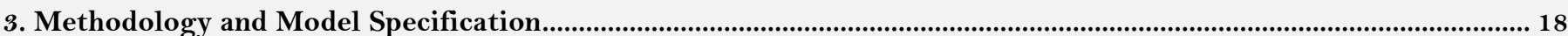

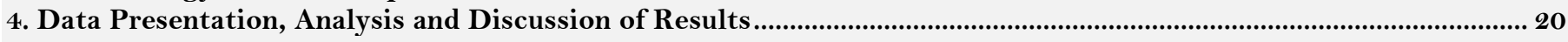

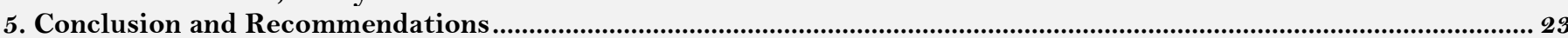

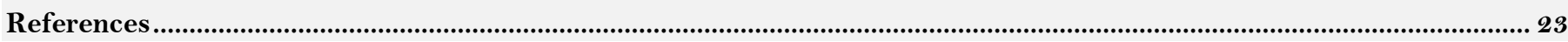

\section{Contribution of this paper to the literature}

This study through the results of the Toda and Yamamoto Multivariate Causality Test showed that the policy objectives of defence and economic growth can be pursued independently in Nigeria and the Republic of Chad.

\section{Introduction}

The attention of researchers in defence economics, a branch of economics that gained recognition in World War II has continued unabated to this day. The impact of military outlay on economic growth has continued to be an issue of great debate after a pioneering work by Benoit (1973); Benoit (1978) that showed a positive link between military outlay and growth in the least Developed Countries (LDCs). This had resulted in the burgeoning of literature either in criticism of Benoit's findings or in defence of it.

The nexus between military outlay and economic growth is a very critical issue considering the current level of insecurity in the Lake Chad Basin Countries that had resulted in the forced displacement of people considered among the world's greatest displacement catastrophe and high level of governments spending particularly, military spending through the Multinational Joint Task Force by the countries affected by the Boko Haram conflict. No wonder, World Bank and UNHCR (2016) in one of their findings stated that:

The Boko Haram insurgency is the greatest single cause of displacement in the Lake Chad region with over 2.5 million people becoming a refugee or an Internally Displaced Person (IDP) as a result of it. This crisis alone accounts for 70 per cent of the total number of people displaced in the four countries (World Bank \& UNHCR, 2016).

However, the outcome of a good number of empirical studies was conflicting or inconsistent. Narayan and Singh (2007) stated, "The Keynesian school of thought contends that an increase in the military burden stimulates demand, increases purchasing power and national output, and creates positive externalities" (p. 395). In contrast, the Classical school of thought are of the view that an expansion of military outlay hinders economic growth. This is because military outlay crowds out private investments due to high-interest rate. Again, a reduction in aggregate demand as a result of a rise in military outlay reduces consumption (Feeny, 2005). The response of the various governments in the conflict-affected countries is military. However, the political will to end the wave of insecurity in the Lake Chad Basin is lacking. From the angle of the Nigerian government, there is no sincerity in the fight against the Boko Haram insurgency.

Hence, military spending had multiplied in the four countries in the Lake Chad region that are bounded by Lake Chad as a result of insecurity. This opinion affirms the argument of Luca (2007) that the desire to guarantee peace and economic growth results in increased military spending. This is not surprising since the eleventh cardinal objective of the Sustainable Development Goals (SDG) is "to make cities and human settlements inclusive, safe, resilient and sustainable" (Osborn, Cutter, \& Ullah, 2015). Furthermore, aligning with the view of Feeny (2005) the perceived threat from Boko Haram had resulted in increased military spending with a reduction in investments that could improve the welfare of these countries. These countries are Cameroon, the Republic of Chad, Niger and Nigeria. Dunne, Smith, and Willenbockel (2005) maintained that war and the absence of security are among the major impediments to development. However, there is no evidence to show whether the huge funds allocated for military spending in the Lake Chad Basin Countries promotes economic growth or retards it.

The observed phenomenon of the rise of military expenditure among these countries bounded by Lake Chad, together with the numerous opinions about the nexus between military outlay and growth, made the subject of the association in the context of two of these countries in the Lake Chad region very appealing. This study will contribute to the existing body of literature and serve as a platform for more study on this subject. Again, the outcome of the study may inform policy on the reallocation of resources from unproductive to productive sectors of the Lake Chad Basin Countries to motivate economic growth. However, to the best of our knowledge, the previous studies in this area are sparse. This investigation intends to study the link between military outlay and economic growth in the Lake Chad Basin countries of the Republic of Chad and Nigeria since they are connected geographically.

Despite the increase in military expenditure over time in these countries bounded by Lake Chad, there has been a fluctuation in economic growth. On average, the trend in the rate of growth of military expenditure and the Gross Domestic Product (GDP) growth rate is unclear. This scenario requires an investigation of the impact of military outlay on economic growth. The questions to answer in this study are: What is the causal link and direction of causality between military expenditure and economic growth in the Republic of Chad and Nigeria? The main objective of this study is to investigate the causal link and direction of causality between military outlay and economic growth in the Republic of Chad and Nigeria.

Besides, the introduction, the rest of the study is organized as follows: Section 2 depicts the literature review and theoretical framework. Section 3 describes the methodology. Section 4 will dwell on data presentation, analysis and discussion of results while section 5 will focus on conclusion and policy recommendations.

\section{Literature Review and Theoretical Framework \\ 2.1. Empirical Literature}

A plethora of literature has investigated the link between defence outlays and economic growth at crosscountry and country by country level for developing and developed countries of the world using diverse 
methodologies. For illustration, applying the Two-Stage Least Squares (2SLS) and simulation method from 1970 to 2008, Anfofum (2011) investigated the nexus between defence outlays and economic growth in Nigeria. The results revealed that defence outlays had a positive and significant effect on agriculture, output of oil and gas, and social services sectors. However, it had a negative impact on the output of manufacturing. Furthermore, defence outlays had a positive and significant impact on economic growth, non-oil exports, oil export, and public investment in Nigeria. The findings of the policy simulation revealed that the impact of defence outlays on the endogenous variables were alike. For instance, economic growth, the output of agriculture, the output of oil and gas, and the output of social services were positive and significant. However, the output of manufacturing remained negative.

Likewise, Tiwari and Shahbaz (2011) used the Autoregressive Distributed Lag (ARDL) method of cointegration to probe the impact of defence expenditures on economic growth in India. The findings signalled a positive impact of defence expenditures on economic growth. However, defence expenditures exerted a negative effect on economic growth after an endpoint. The result of Granger causality revealed a bidirectional causality between defence expenditures and economic growth. In another similar study and applying the Three-Stage Least Squares (3SLS) in the framework of the augmented growth model of Solow, Chairil, Sinaga, and Febrianti (2013) investigated the link between military spending and economic growth in the Association of South-East Asian Nations (ASEAN) region with emphasis on Indonesia. The findings revealed that military expenditure impacted economic growth positively. The causality result showed that there is a bidirectional causal relationship between military spending and economic growth in Indonesia.

Also, this survey comprising of almost 170 works conducted by Dunne and Tian (2013) extended and updated an initial literature survey on the association between military spending and economic growth. It revealed that current studies employing data as far back as the end of the cold war provided progressively robust evidence of the generally negative impact of military spending on economic growth. Similarly, Haseeb (2014) used the ARDL bounds testing method to cointegration from 1975 to 2010 to investigate the link between defence spending and economic growth and considered the likelihood of defence spending being utilized as an instrument for stabilization of macroeconomics denoted as the Military Keynesianism Hypothesis in Pakistan. The findings revealed that defence spending had a negative effect on economic growth. The findings imply that Military Keynesianism Hypothesis does not hold for Pakistan.

Apanisile and Okunlola (2014) in the same way used the Autoregressive Distributed Lag Technique (ARDL) to cointegration from 1989 to 2013 to examine the short-run and long-run impact of military expenditure on growth in Nigeria. The study also confirmed whether military spending is an economically non-contributive activity in the contemporary world as proposed by Dumas (2002). The findings revealed that military expenditures exerted a negative and significant impact on economic growth in the short run. However, its effect on economic growth was positive and significant in the long run. Contrary to the suggestion of Dumas (2002) the study concluded that military spending is an economically contributive activity. Utilizing panel data technique from 2005 to 2012, Feeny (2005) also studied the link between military expenditures and economic growth in 10 countries in the Mediterranean region. The findings revealed that military spending exerted a negative impact on economic growth in these countries.

Furthermore, employing techniques of exogenous growth and dynamic panel data on a large and balanced panel data from 1988 to 2010 for a pool of 104 countries, Dunne and Tian (2015) investigated the impact of military expenditure on economic growth. The findings showed a significant negative effect of military spending on economic growth for the entire sample. However, the impact was greater in countries in Africa. The results indicated an undeniable degree of heterogeneity. Furthermore, it showed that the effect of military spending on economic growth was insignificant for middle-income countries in Africa, countries in Africa that never suffered conflict, non-African countries with natural resources abundance, and non-African countries whose economies are reasonably closed.

Using the augmented Solow model, fixed effect estimator or the Least Square Dummy Variable (LSDV) and employing current data from 1988 to 2015 for a group of 61 countries, Arshad, Syed, and Shabbir (2017) in a related study explored the joint impact of military expenditure and armed conflicts on economic growth. The results showed that military expenditure and arms imports exerted a negative effect on per capita GDP. However, military spending had a negative and significant effect on economic growth where external conflicts exist.

Ajmair, Hussain, Abbassi, and Gohar (2018) in another study used time series data throughout 1990-2015 and the ARDL technique to cointegration to investigate the short-run and long-run nexus between military spending, number of persons in military and economic growth in Pakistan. The findings revealed that military spending in Pakistan had a positive and insignificant relationship with economic growth. However, number of persons in the military exerted a positive and significant relationship with economic growth in the long run. The short-run result showed that military spending and the number of persons in the military had a positive and significant link with economic growth.

Raju and Ahmed (2019) used the Engle-Granger cointegration technique in a similar study to investigate the short-run and long-run nexus between military spending and economic growth in India, Pakistan and China using 1980-2017, 1989-2017 and 1989-2017 respectively as ranges of data. The long-run results showed that military spending had a positive relationship with economic growth in the three countries. However, the short-run results revealed the absence of a link between military spending and economic growth in the three countries. The causality results showed a unidirectional causal relationship from military spending to economic growth in the three countries.

Utilizing the heterogeneous panel causality test, Generalized Method of Moments (GMM) and System Generalized Method of Moments techniques and using data from 1990-2015, Saba and Ngepah (2019) as well examined the causal link between military spending and economic growth for a balanced panel of 35 countries in Africa. The results of the causality test conducted on a country by country basis showed: unidirectional causal relationship from military spending to economic growth in two countries; unidirectional causality from economic growth to military spending in 14 countries; bidirectional causality in 12 countries and no causal link between military expenditure and economic growth in seven countries. Cetin and Guzel (2019) on the same subject used 
panel econometric models from 1990 to 2017 to examine the nexus between military spending and economic growth in the Middle East and North African (MENA) Countries. The result revealed a negative and significant relationship between military spending and economic growth in MENA countries.

Evidence from past studies on the nexus between military outlay and economic growth in the context of developing and developed countries of the world has revealed inconsistent results. Smith (1994) and Mintz and Stevenson (1995) argued that shortcomings in theory and methodologies are the probable reasons for disagreement in the literature. However, Alexander (1990); Ram (1995) and Alptekin and Levine (2012) opined that the use of different datasets, periods and empirical models are principally responsible for the diverse results. The attention of the majority of the studies was on developed countries. However, developing countries were mainly included in cross country studies. Most of the studies were cross-sectional studies. On the other hand, country-specific studies utilizing time series techniques were few.

Furthermore, evidence from previous literature showed that the inability to generalize the link between military outlay and economic growth for all countries prompted some scholars to unearth joint features for countries that are alike. Relying on their commonalities, they grouped countries as non-conflict and conflict states (Looney, 1988b) dependent on geography (Gyimah-Brempong, 1989) regional sensitivity (Heo, 1996; Kollias, 1994; Kollias, 1995; Kollias \& Makrydakis, 1997; Ocal, 2002) organization (Hassan, Waheeduzzaman, \& Rahman, 2003) being high/low growth or developed/developing countries (Benoit, 1978; Biswas \& Ram, 1986; Dakurah, Davies, \& Sampath, 2001; Deger, 1986) countries that are experiencing foreign-exchange constraints, and countries which are well-endowed with resources (Looney \& Frederiksen, 1986b).

The nexus between military outlays and economic growth was found to be positive by some scholars (Ajmair et al., 2018; Ando, 2008; Anfofum, 2011; Apanisile \& Okunlola, 2014; Atesoglu \& Mueller, 1990; Babin, 1986; Benoit, 1978; Biswas, 1993; Bose, Haque, \& Osborn, 2003; Candar, 2003; Chairil et al., 2013; Frederiksen \& McNab, 2001; Halicioglu, 2004; Hassan et al., 2003; Kennedy, 1983; Mueller \& Atesoglu, 1993; Stewart, 1991; Tiwari \& Shahbaz, 2011 ; Ward, Davis, Penubarti, Rajmaira, \& Cochran, 1991; Weede, 1983; Yildirim, Sezgin, \& Öcal, 2005). Others found a negative relationship (Abu-Bader \& Abu-Qarn, 2003; Arshad et al., 2017; Brasoveanu, 2010; Cetin \& Guzel, 2019; Deger, 1986; Deger \& Smith, 1983; Dunne, 2010; Dunne, Nikolaidou, \& Smith, 2002; Dunne \& Tian, 2013; Dunne, 2012; Faini, Annez, \& Taylor, 1984; Feeny, 2005; Galvin, 2003; Guaresma \& Reitschuler, 2003; Haseeb, 2014; Heo, 2010; Hou, 2010; Hou \& Chen, 2013; Iftikhar ul Husnain \& Shaheen, 2011; Karagol \& Palaz, 2004; Kentor \& Kick, 2008; Klein, 2004; Lim, 1983; Mylonidis, 2008; Sezgin \& Yildirim, 2002; Shahbaz, Afza, \& Shabbir, 2013; Smith \& Tuttle, 2008; Tekeoglu, 2008).

Some scholars found no relationship (Adams, Behrman, \& Boldin, 1991; Aizenman \& Glick, 2006; Alexander, 1990; Benoit, 1973; Biswas \& Ram, 1986; DeRouen, 1994; Gerace, 2002; Habibullah, Law, \& Dayang-Afizzah, 2008; Huang \& Mintz, 1990; Huang \& Mintz, 1991; Kinsella, 1990; Park, 1993; Payne \& Ross, 1992; Ward \& Davis, 1992). In the contention of Brasoveanu (2010) the results of some studies vary. It might reveal either positive or negative correlations between military outlay and economic growth (Biswas \& Ram, 1986; Chowdhury, 1991; Guaresma \& Reitschuler, 2003; Heo, 1998; Karagol \& Palaz, 2004; Looney, 1988a, 1988b; Looney \& Frederiksen, 1986b; Wilkins, 2004). However, it is common in cross-country studies.

Furthermore, the previous studies revealed that there are four types of causal relationships between military expenditure and growth. These are unidirectional causality from military outlay to economic growth, unidirectional causality from economic growth to military outlay, bidirectional causality between military outlay and economic growth and no causality between military outlay and economic growth. The review of the literature showed that several studies have explored the nexus between military outlay and economic growth. However, the studies that investigated the impact of military outlay on economic growth in the Republic of Chad and Nigeria were sparse. Therefore, this study intends to contribute to the prevailing literature by examining the link between military outlay and economic growth in the context of the Republic of Chad and Nigeria since they are connected geographically and currently experiencing conflicts.

\subsection{Theoretical Review}

There is no agreement in terms of theory regarding the effect and causal link between military outlay and economic growth. Dunne and Coulomb (2008) argued that the absence of a generally accepted theory among scholars in economics has led to the incorporation of military expenditure into growth by diverse schools of thought. Hence, there are four main theories in the literature for examining the impact of military outlay on economic growth. These are Neoclassical, Keynesian, Institutional and Marxist theories. These theories have advocated numerous connections between military outlay and economic growth that can be broadly categorized into supply-side effects, demand-side effects and security effects.

The neoclassical theory believes that the state is a rational actor that equalizes the opportunity costs and security benefits of military outlay to maximize national interest. The shortcoming of this theory is that it merely focuses on the probable outside enemy of the state thereby disregarding the internal responsibility of the military. Biswas and Ram (1986) claimed that the Feder-Ram model is the most prominent strand of the neoclassical theory. However, in recent times, it was severely criticized by Dunne et al. (2005). One of the flaws of this theory is that it disregards the demand side on the assumption that it is in equilibrium with the supply constraints of the economy. Furthermore, it believes that physical labour and capital are the only components of the production function (Nikolaidou (1999). This eliminates the element of human capital such as education, talent and acquired skills from the output equation. Another flaw is the restriction of the model due to its concentration on the two-sector model. This implies the government and export sectors should be added to that model. Besides, multicollinearity between the share in Gross Domestic Product (GDP) and growth rate of each of the sectors is unavoidable, and hence,

The estimates may not provide a good feel for the magnitude of the externality effect and/or the productivity differences and .... as is common with most single-equation models, there are some measurement and data problems and there may be 'feedback' from the dependent variable to some of the regressors (Ram, 1995).

Nikolaidou (1999) argued that regardless of the limitations of the Feder-Ram model, their advantages that outweigh their defects should not be overlooked. On the other, hand, the Keynesian and Institutional models that 
relate military outlays to economic growth through the supply and demand side conduits proposes that when the state uses its funds for military expenditure, economic growth is boosted through the multiplier process in the face of weak aggregate demand (Dunne \& Uye, 2010). Hence, increased investment and economic growth results from increased capacity utilization and increased profits caused by military spending (Faini et al., 1984). Hence, provided that military outlay is autonomous, this model justifies the military expenditure.

The Marxist theory emphasizes the importance of military outlay in the growth of the capitalist economic system through the sustenance of effective demand and avoidance of a drop in the rate of profit (Coulomb \& Bellais, 2008). Thus, as a result of military expenditure, economic breakdown and crisis are averted. Several components of this theory diverge in their management of the crisis, the role of military outlay in the development of capitalism and the role of the military-industrial complex in the class struggle.

The under consumptionist approach, for instance, argues that military outlay is critical in foiling realization crisis that results from excessive growth of productive forces and output over the growth of effective demand thereby putting pressure on wages. Thus, by incorporating capital with no reduction in wages and conserving profit, military expenditure counteracts the crisis (Dunne, 1990). In the contention of Smith (1977) and Coloumb (2004) despite the influential nature of this approach in the literature of economic development, empirical studies in this approach have been limited to developed countries.

\subsection{Theoretical Framework}

Feder (1983); and Feder (1986) model for the analysis of the link between exports and economic growth in developing countries adopted by Biswas and Ram (1986) for a cross-country investigation of the relationship between military outlay and economic growth was used in this study. The model was utilized as a result of a direct relationship from theory to econometric specification. Again, the model depicts the externality effect of military production outlay on production of the civilian sector. Hence, following Maingi (2010) with some modifications, this theoretical model for the analysis of the link between military outlay and economic growth follows Dunne et al. (2005) model.

The model is a two-sector model comprising of output of the military $(\mathrm{M})$ and output of the civilian (C). Capital $(\mathrm{K})$ and labour $(\mathrm{L})$ allocation in these sectors is such that:

and

$$
K=K_{M}+K_{C}
$$

$$
L=L_{M}+L_{C}
$$

$\mathrm{M}$ was incorporated into the output equation of the civilian sector $\mathrm{C}$ in Equation 3 to capture the externalities associated with the defence sector. This externality effect can either be in form of a positive marginal product for defence in Equation 3 or as a relative factor productivity differential for capital and labour in both sectors.

$$
\begin{aligned}
& C=C\left(K_{C}, L_{C}, M\right) \\
& M=M\left(K_{M}, L_{M}\right)
\end{aligned}
$$

Where $K_{C}, K_{M}, L_{C}, L_{M}$ are inputs of capital and labour allocated to civilian and military production activities respectively.

Imagining a constant productivity differential between labour in the two sectors:

$$
\frac{M_{L}}{C_{L}}=\frac{M_{K}}{C_{K}}=(1+\delta)
$$

where $\delta>0$ suggests lower productivity in the military sector (the reverse would be the case if $\delta<0$ ) and $\delta \neq 0$

Hence, the total supplies of capital and labour based on Equations 1 and 2 is:

$$
Y=M+C
$$

Substituting Equations 3 and 4 into Equation 6, yields:

$Y=M\left(K_{M}\right.$
Taking the total differential of Equation 7 gives:

$$
\begin{gathered}
d Y=\frac{\partial M}{\partial K_{M}} \cdot d K_{M}+\frac{\partial M}{\partial L_{M}} \cdot d L_{M}+\frac{\partial C}{\partial K_{C}} \cdot d K_{C}+\frac{\partial C}{\partial L_{C}} \cdot d L_{C}+\frac{\partial C}{\partial M} \cdot d M \\
d Y=M_{K} d K_{M}+M_{L} d L_{M}+C_{K} d K_{C}+C_{L} d L_{C}+C_{M} d_{M}
\end{gathered}
$$

Rearranging the result yields:

$$
\begin{gathered}
d Y=M_{K} d K_{M}+C_{K} d K_{C}+M_{L} d L_{M}+C_{L} d L_{C}+C_{M} d_{M} \\
\text { Where: }
\end{gathered}
$$

$M_{K}$ and $C_{K}=$ Marginal products of input $K$ in sectors $M$ and $C$ $M_{L}$ and $C_{L}=$ Marginal products of input $L$ in sectors $M$ and $C$

From Equation 5: $C_{M}=$ Marginal externality effect of military on civilian sector

Substituting Equation 9 into Equation 8 and rearranging

$$
\begin{array}{r}
\text { Rearranging yields: } \\
d Y=M_{K} d K_{M}+C_{K} d K_{C}+C_{L} d L_{M}+C_{L} d L_{C}+\delta C_{L} d L_{M}+C_{M} d_{M} \\
d Y=M_{K} d K_{M}+C_{K} d K_{C}+C_{L}\left(d L_{M}+d L_{C}\right)+\delta C_{L} d L_{M}+C_{M} d_{M}
\end{array}
$$

$$
\begin{gathered}
d Y=M_{K} d K_{M}+C_{K} d K_{C}+M_{L} d L_{M}+C_{L} d L_{C}+C_{M} d_{M} \\
d Y=M_{K} d K_{M}+C_{K} d K_{C}+C_{L} d L_{M}+\delta C_{L} d L_{M}+C_{L} d L_{C}+C_{M} d_{M}
\end{gathered}
$$

Totally differentiating Equation 4 gives:

$$
\begin{aligned}
& d M=\frac{\partial M}{\partial K_{M}} \cdot d K_{M}+\frac{\partial M}{\partial L_{M}} \cdot d L_{M} \\
& d M=M_{K} d K_{M}+M_{L} d L_{M} \\
& d M=M_{K} d K_{M}+(1+\delta) C_{L} d L_{M}
\end{aligned}
$$

Substituting Equation 9 into Equation 11 yields Equation 12 


$$
d M-M_{K} d K_{M}=(1+\delta) C_{L} d L_{M}
$$

Dividing both sides of Equation 13 by $(1+\delta)$, we have:

$$
\frac{d M}{(1+\delta)}-\frac{M_{K}}{(1+\delta)} d K_{M}=C_{L} d L_{M}
$$

Substituting Equation 14 into Equation 10 and collecting like terms yields:

$$
\begin{gathered}
d Y=M_{K} d K_{M}+C_{K} d K_{C}+C_{L}\left(d L_{M}+d L_{C}\right)+\delta\left[\frac{d M}{(1+\delta)}-\frac{M_{K}}{(1+\delta)} d K_{M}\right]+C_{M} d_{M} \\
d Y=M_{K} d K_{M}+C_{K} d K_{C}+C_{L} d L_{M}+C_{L} d L_{C}+\delta\left[\frac{d M}{(1+\delta)}-\frac{M_{K}}{(1+\delta)} d K_{M}\right]+C_{M} d_{M} \\
d Y=C_{K} d K_{C}+C_{L} d L_{C}+M_{K} d K_{M}+\left[\frac{d M}{(1+\delta)}-\frac{M_{K} d K_{M}}{(1+\delta)}\right]+\delta\left[\frac{d M}{(1+\delta)}-\frac{M_{K}}{(1+\delta)} d K_{M}\right]+C_{M} d_{M} \\
d Y=C_{K} d K_{C}+C_{L} d L_{C}+M_{K} d K_{M}+(1+\delta)\left[\frac{d M}{(1+\delta)}-\frac{M_{K} d K_{M}}{(1+\delta)}\right]+C_{M} d_{M} \\
d Y=C_{K} d K_{C}+C_{L} d L_{C}+M_{K} d K_{M}+d M-M_{K} d K_{M}+C_{M} d_{M} \\
d Y=C_{K} d K_{C}+C_{L} d L_{C}+\left(1+C_{M}\right) d_{M}
\end{gathered}
$$

Supposing there is a linear link between the marginal products of labour in each sector and the average output per unit of labour in the economy, that is:

$$
C_{L}=\left[\frac{Y}{L}\right]
$$

Assume that Gross Fixed Capital Formation is denoted by $d K_{C}$ $=I$ and substitute it into Equation 15 to have:

Dividing Equation 16 by Y gives:

$$
d Y=C_{K} I+C_{L} d L_{C}+\left(1+C_{M}\right) d_{M}
$$

$$
\begin{array}{r}
\frac{d Y}{Y}=\frac{C_{K} I}{Y}+\frac{C_{L} d L_{C}}{Y}+\frac{\left(1+C_{M}\right) d_{M}}{Y} \\
C_{L}=\frac{Y}{L} \\
\frac{d Y}{Y}=C_{K} \frac{I}{Y}+\frac{\frac{Y}{L} d L_{C}}{Y}+\frac{\left(1+C_{M}\right) d_{M}}{Y} \\
\frac{d Y}{Y}=C_{K} \frac{I}{Y}+\frac{d L_{C}}{L}+\frac{\left(1+C_{M}\right) d_{M}}{Y}
\end{array}
$$

Supposing $C_{K}=\beta,\left(1+C_{M}\right)=\gamma$ and $\frac{d L_{C}}{L}=\rho$, Equation 17 becomes:

$$
\begin{gathered}
\frac{d Y}{Y}=\beta \frac{I}{Y}+\rho \frac{d L_{C}}{L}+\gamma \frac{d_{M}}{Y} \\
\frac{d Y}{Y}=\text { Measure of economic growth } \\
\frac{I}{Y}=\text { Gross fixed capital formation as a share of GDP } \\
\frac{d L_{C}}{L}=\text { Growth rate of the labour force } \\
\frac{d_{M}}{Y}=\text { Military outlay as a share of GDP }
\end{gathered}
$$

Equation 18 is similar to Ram (1986) economic growth equation and would form the basis for estimation of empirical model in the methodology.

Hence, this theoretical framework forecasts that growth $(\mathrm{d} Y / \mathrm{Y})$ depends on gross fixed capital formation as a share of GDP, growth rate of the labour force $\left(\mathrm{dL}_{\mathrm{C}} / \mathrm{Y}\right)$ and military expenditure as a percentage share of GDP.

\subsection{Trend of Real Gross Domestic Product and Military Outlay in Countries in the Lake Chad Basin 2.4.1. Trend of Real Gross Domestic Product and Military Outlay in the Republic of Chad}

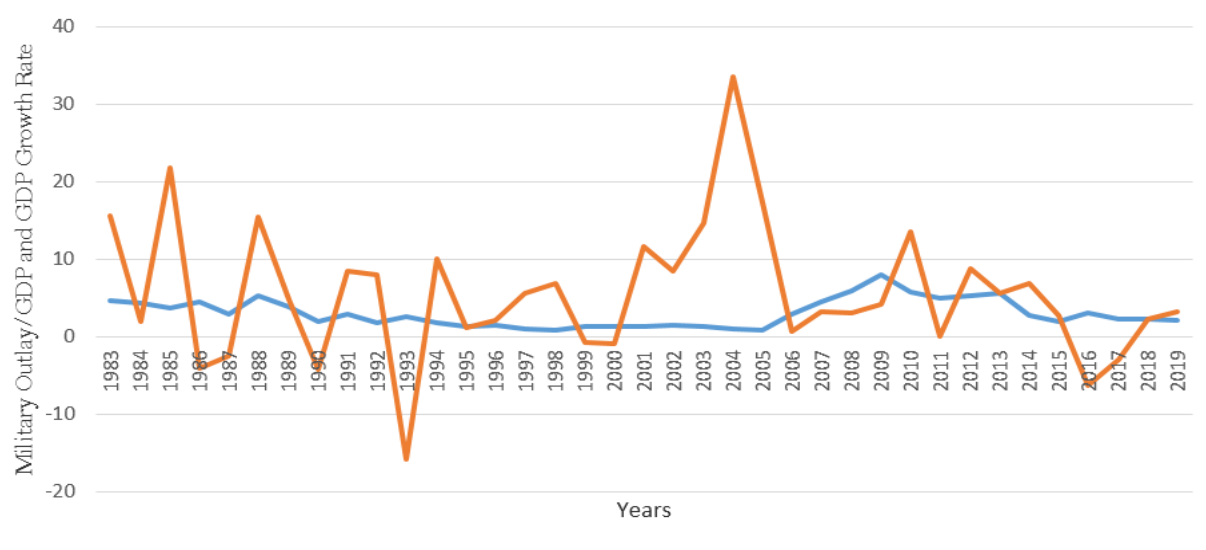

Figure-1. Military outlay as a share of GDP and annual growth rate of GDP, 1983-2019. Source: World Bank, World Development Indicators (WDI) database. 
The trend in military outlay as a percentage of GDP and annual growth rate of GDP in the Republic of Chad for the study period is shown in Figure 1. The GDP growth rate of the Republic of Chad recorded positive values from 1983-1985, 1988-1989, 1994-1998, 2001-2015 and 2018-2019 respectively. The growth rate of 2018 was a sign of recovery after deep recessions in two years. However, it recorded negative values from 1986-1987, 1990, 1993, 1999-2000 and 2016-2017 respectively. The drop in international prices of oil accounted for the recessions of 2016 and 2017 respectively. The rates of growth between the annual rate of growth of GDP and military outlay varies. However, the GDP growth rate has been growing at a better rate than military outlay. The highest growth rate of GDP was recorded in 2004. On the other hand, the lowest growth rate of the economy was in 1993. Military outlay as a percentage of GDP maintained positive values throughout the study period. In recent times, the economy of the Republic of Chad has been fragile and vulnerable to volatility in oil prices and insecurity in the Lake Chad region. The landlocked status of Chad had impeded its economic progress seriously. It relies on the Cameroonian seaports for exports and imports. The extensive corruption in Cameroon most often results in inflation in the costs of transportation of exported and imported goods and services.

\subsubsection{Trend of Real Gross Domestic Product and Military Outlay in Nigeria}

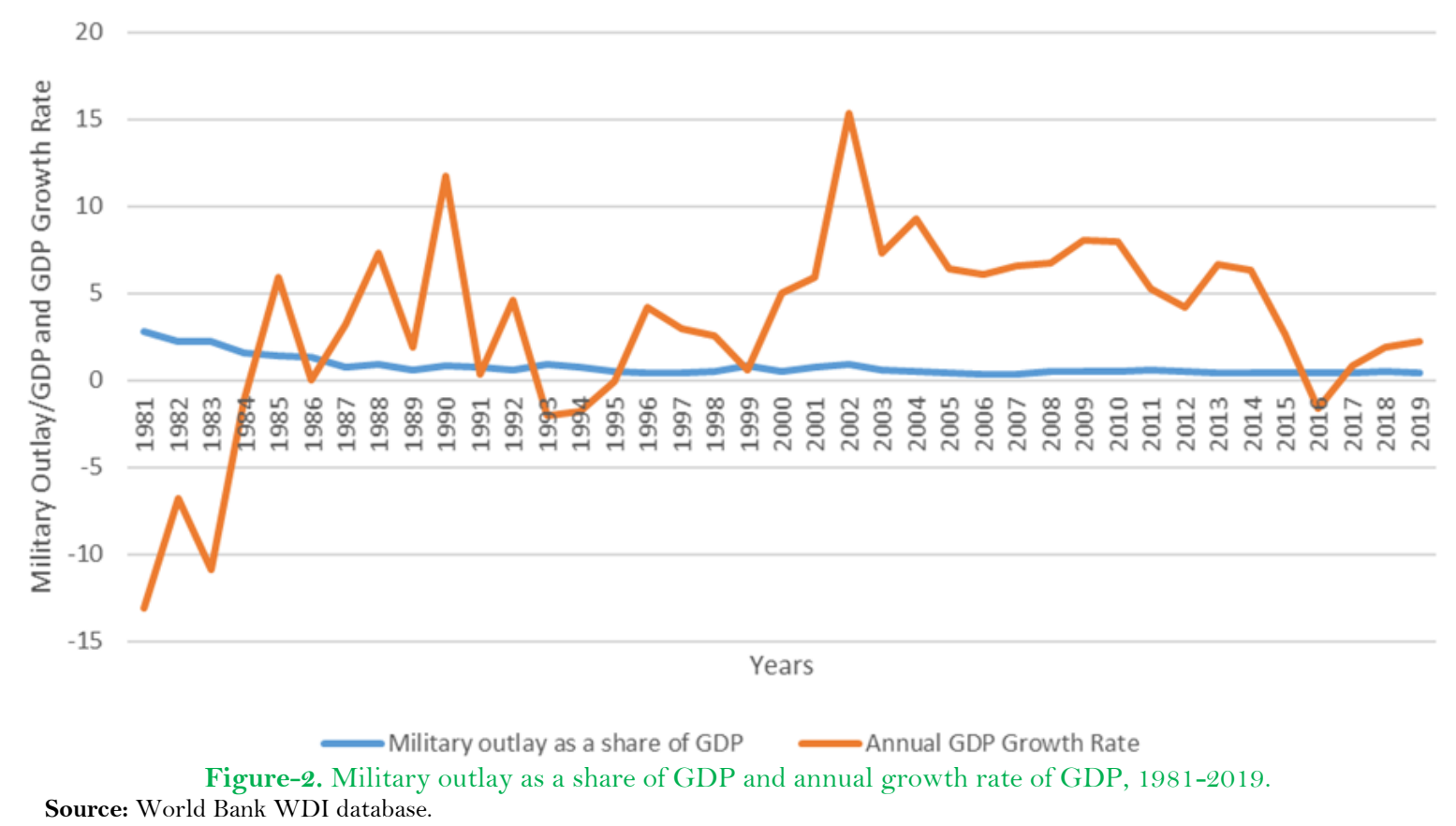

Figure 2 depicts the trend in military outlay as a percentage of GDP and the annual growth rate of GDP in Nigeria for the study period. The GDP growth rate of Nigeria recorded positive values for most of the years under review. However, it recorded negative values from 1981-1984, 1993-1995 and 2016 respectively. The negative GDP growth rates from 1981-1984 were as a result of a drop in Nigeria's economic fortunes (Mordi, Englama, \& Adebusuyi, 2010). This period was characterized by a serious drop in the international prices of oil. The negative growth rate of 2016 resulted in a recession. The recession was caused by foreign exchange restrictions, unfavourable economic policies, low production and a drop in oil prices in the international oil market. However, the situation was worsened by attacks on oil and gas facilities in the Niger Delta region by militants. GDP growth turned positive in 2017 as oil prices recovered and output stabilized.

The rates of growth between the annual rate of growth of GDP and military outlay varies. However, the GDP growth rate has been growing at a better rate than military outlay. The highest growth rate of GDP was recorded in 2002. On the other hand, the lowest growth rate of the economy was in 1981. The GDP growth rate for 2014 was remarkable. In that year, Nigeria became the leading economy in Africa. From 2003- 2019, military outlay as a percentage of GDP was almost O per cent. The annual growth rate of GDP declined from 1981 to 1984 . It recorded zero values for 1986 and 1991. However, it exhibited an upward and downward trend from 1987-1990.

\section{Methodology and Model Specification}

Our empirical estimation will start with a modified version of Equation 18 specified as Equation 19, with trade openness included as inputs into the production function.

$$
\frac{d Y}{Y}=\beta \frac{I}{Y}+\rho \frac{d L_{C}}{L}+\gamma \frac{d_{M}}{Y}+\mu_{t}
$$

\section{$\mu_{t}=$ disturbance term}

This study would build on Saba and Ngepah (2019) model with some modifications. On the basis of modified growth model of Ram (1986) an empirical model for the analysis of the link between military outlay and economic growth is specified as Equation 20 and has the following form:

$$
\begin{gathered}
\text { RGDPPC }=f(G F C F, \text { MILEXP, TOPEN }) \\
\text { Where }: \\
\text { RGDPPC = Real Gross Domestic Product per capita } \\
\text { GFCF = Gross Fixed Capital Formation as a share of GDP } \\
\text { MILEXP = Military outlay as a share of GDP } \\
\text { TOPEN = Exports plus Imports as a percentage share of GDP }
\end{gathered}
$$


The long-run model for estimation is:

$$
\log \left(R G D P P C_{t}\right)=\propto+\beta_{1} G F C F_{t}+\beta_{2} M_{L I E X P_{t}}+\beta_{3} \text { TOPEN }_{t}+\mu_{t}
$$

The study used secondary data ranges from 1981 to 2019 and 1983 to 2019 for Nigeria and the Republic of Chad respectively. The time frame for the study was based on the availability of data. In the case of the Republic of Chad, the data on military expenditure as a percentage share of GDP were not available for 1991 and 2012 respectively. Hence, extrapolation was employed to fill the gap. The time series data on growth rate of the labour force was not available. Hence, it was dropped. All the data were derived from World Bank's (WB), World Development Indicators (WDI) database. The study used the Auto-Regressive Distributed Lag (ARDL) method of cointegration elaborated by Pesaran, Shin, and Smith (2001). The Augmented Dickey-Fuller and Phillips-Perron (PP) unit root tests were employed to check the time-series properties of the data prior to the economic growth equation estimation. Definitions, measures, sources and expected signs of the variables used in this study are shown in Table 1.

Table-1. Definitions, measures, sources and expected signs of variables utilized in this study.

\begin{tabular}{|c|c|c|c|}
\hline Variables & Definition and/or proxy & Data Source & Expected Sign \\
\hline \multicolumn{4}{|l|}{ Dependent Variable } \\
\hline $\begin{array}{l}\text { GDP per Capita growth rate } \\
\text { (RGDPPC) }\end{array}$ & $\begin{array}{l}\text { Real Gross Domestic Product (GDP) per } \\
\text { capita (Constant } 2010 \text { US } \$ \text { ) }\end{array}$ & WB, WDI & $\begin{array}{l}\text { Dependent } \\
\text { Variable }\end{array}$ \\
\hline \multicolumn{4}{|l|}{ Independent Variables } \\
\hline $\begin{array}{l}\text { Gross fixed capital formation } \\
(\text { GFCF })\end{array}$ & $\begin{array}{l}\text { Gross fixed capital formation (\% of } \\
\text { GDP). Proxy for physical capital or } \\
\text { investment }\end{array}$ & WB, WDI & + \\
\hline Military expenditure (MILEXP) & $\begin{array}{l}\text { Military expenditure as a percentage } \\
\text { share of GDP }\end{array}$ & WB, WDI & - \\
\hline Trade openness (TOPEN) & $\begin{array}{l}\text { The openness of the economy was } \\
\text { measured by exports plus imports as a } \\
\text { percentage share of GDP }\end{array}$ & WB, WDI & + \\
\hline
\end{tabular}

Representing Equation 21 in ARDL form gives:

$\log \left(R G D P P C_{t}\right)$

$$
\begin{aligned}
& =\propto_{0}+\sum_{i=1}^{\rho} \propto_{1} \Delta \log \left(R G D P P C_{t-i}\right)+\sum_{i=1}^{\rho} \propto_{2} \Delta G F C F_{t-i}+\sum_{i=1}^{\rho} \propto_{3} \Delta M I L E X P_{t-i} \\
& +\sum_{i=1}^{\rho} \propto_{4} \Delta \operatorname{TOPEN}_{t-i}+\beta_{1} \log \left(R G D P P C_{t-i}\right)+\beta_{2} G F C F_{t-i}+\beta_{3} M I L E X P_{t-i}+\beta_{4} \text { TOPEN }_{t-i} \\
& +\mu_{t}
\end{aligned}
$$

Where $\mathrm{p}$ and $\Delta$ denote the lag length and difference operator. $\alpha_{0}$ and $\mu_{\mathrm{t}}$ signify the drift and disturbance term. The parameters of the short-run dynamics are $\alpha_{1}, \alpha_{2}, \alpha_{3}$, and $\alpha_{4}$. On the other hand, $\beta_{1}, \beta_{2}, \beta_{3}$ and $\beta_{4}$ are the parameters of the long-run relationship.

The null and alternative hypotheses of no cointegration and cointegration respectively can be verified by comparing the computed F-statistic with critical value bounds for the lower bound $\mathrm{I}(0)$ and upper bound $\mathrm{I}(1)$ respectively. In Equation 22, the coefficients that would be verified under the null and alternative hypotheses of no cointegration and cointegration between economic growth and the causal factors are stated as: against:

$$
H_{0}: \beta_{1}=\beta_{2}=\beta_{3}=\beta_{4}=0
$$

$$
H_{1}: \beta_{1} \neq \beta_{2} \neq \beta_{3} \neq \beta_{4} \neq 0
$$

If the $\mathrm{F}$-statistic is below the critical value for the lower bound $\mathrm{I}(\mathrm{O})$, the conclusion would be absence of cointegration and no long-run relationship. On the other hand, If the computed F-statistic exceeds the critical value bounds for the upper bound I(1), the conclusion would be the existence of cointegration among the variables. Hence, a long-run relationship exists. However, if the value of the $\mathrm{F}$-statistic is between the lower $\mathrm{I}(0)$ and upper $\mathrm{I}(1)$ bounds, the test is considered inconclusive.

If cointegration does not exist among the variables, the procedure would cease. However, short-run and longrun parameters would be estimated if there is cointegration among the variables. The long-run model to be estimated in the presence of a long-run relationship is specified in Equation 23 as: $\log \left(R G D P P C_{t}\right)$

$$
\begin{aligned}
& =\propto_{0}+\sum_{i=1}^{\rho} \propto_{1} \Delta \log \left(\operatorname{RGDPPC}_{t-i}\right)+\sum_{i=1}^{\rho} \propto_{2} \Delta G F C F_{t-i}+\sum_{i=1}^{\rho} \propto_{3} \Delta M I L E X P_{t-i} \\
& +\sum_{i=1}^{\rho} \propto_{4} \Delta \operatorname{TOPEN}_{t-i}+\mu_{t}
\end{aligned}
$$

The evaluation of the error correction model would be the last step. Thus, the specification of the short-run dynamic in ARDL form can be obtained through the construction of an error correction model linked with the long-run estimates as shown in Equation 24. 
$\Delta \log \left(R G D P P C_{t}\right)$

$$
\begin{aligned}
& =\propto_{0}+\sum_{i=1}^{\rho} \propto_{1} \Delta \log \left(\operatorname{RGDPPC}_{t-i}\right)+\sum_{i=1}^{\rho} \propto_{2, i} \Delta G F C F_{t-i}+\sum_{i=1}^{\rho} \propto_{3} \Delta M I L E X P_{t-i} \\
& +\sum_{i=1}^{\rho} \propto_{4} \Delta \operatorname{TOPEN}_{t-i}+\pi e c m_{t-i}+\mu_{t}
\end{aligned}
$$

Where $\alpha_{1}, \alpha_{2}, \alpha_{3}, \alpha_{4}$ are the short-run dynamics parameters, $\pi$ represents the speed of adjustment and ecm ${ }_{t-1}$ denotes the error correction term. The speed of adjustment is expected to be negative and significant to verify the existence of cointegration among the variables.

\section{Data Presentation, Analysis and Discussion of Results

\begin{tabular}{|c|c|c|c|c|c|c|c|}
\hline \multirow[t]{2}{*}{ Country } & \multirow[t]{2}{*}{ Variable } & \multicolumn{3}{|c|}{ Augmented Dickey-Fuller (ADF) } & \multicolumn{3}{|c|}{ Phillips-Perron (PP) } \\
\hline & & Level & $\begin{array}{c}\text { First } \\
\text { Difference }\end{array}$ & $\mathbf{I}(\mathbf{d})$ & Level & $\begin{array}{c}\text { First } \\
\text { Difference }\end{array}$ & $\mathbf{I}(\mathbf{d})$ \\
\hline \multirow[t]{4}{*}{ Nigeria } & Log(RGDPPC) & -0.9450 & $-3.8744^{* * *}$ & $\mathrm{I}(1)$ & -0.3115 & $-3.8745^{* * * *}$ & $\mathrm{I}(1)$ \\
\hline & GFCF & $-3.6171 * * *$ & - & $\mathrm{I}(0)$ & $-3.5398 * * *$ & - & $\mathrm{I}(\mathrm{O})$ \\
\hline & MILEXP & $-4.7338 * * *$ & - & $\mathrm{I}(0)$ & $-5.8790^{* * * *}$ & - & $\mathrm{I}(\mathrm{O})$ \\
\hline & TOPEN & -2.3082 & $-7.4777 * * *$ & $\mathrm{I}(1)$ & -2.2206 & $-8.0386^{* * * *}$ & $\mathrm{I}(1)$ \\
\hline \multirow[t]{4}{*}{ Chad } & Log(RGDPPC) & -0.9895 & $-5.3997 * * *$ & $\mathrm{I}(1)$ & -1.0598 & $-5.4073^{*} * *$ & $\mathrm{I}(1)$ \\
\hline & GFCF & -2.5844 & $-5.5364^{* * * *}$ & $\mathrm{I}(1)$ & -1.8033 & $-5.3236^{* * * *}$ & $\mathrm{I}(1)$ \\
\hline & MILEXP & -2.1152 & $-6.4923^{* * * *}$ & $\mathrm{I}(1)$ & -2.2039 & $-6.5014^{* * * *}$ & $\mathrm{I}(1)$ \\
\hline & TOPEN & -1.5561 & $-9.1811^{* * * *}$ & $\mathrm{I}(1)$ & -2.2767 & $-9.2988^{* * * *}$ & $\mathrm{I}(1)$ \\
\hline
\end{tabular} \\ 4.1. Augmented Dickey-Fuller (ADF) and Phillips-Perron (PP) Unit Root Tests Results on Series}

The ADF and PP unit root tests results are shown in Table 2. The results for Nigeria revealed that the variables were either $\mathrm{I}(0)$ or $\mathrm{I}(1)$. The variables (GFCF and MILEXP) were integrated at the level $\mathrm{I}(0)$ whereas the remainder were integrated at the first difference $\mathrm{I}(1)$. On the other hand, the unit root results for the Republic of Chad showed that all the variables were integrated at the first difference. Since the regressors for Chad exhibited only I(1) and those for Nigeria showed a mixture of $\mathrm{I}(0)$ and $\mathrm{I}(1)$, the application of the ARDL approach is justified. The PP test for unit root confirmed the ADF results.

\subsection{Results of Diagnostic Tests for ARDL Model}

Table-3. Diagnostic results for ARDL model.

\begin{tabular}{l|c|c|l|l}
\hline Country: Nigeria & Test Statistic & P-value & Null Hypothesis & Conclusion \\
\hline Test Serial & 0.1455 & 0.8654 & $\mathrm{H}_{\mathrm{o}}$ : No serial correlation & Cannot reject $\mathrm{H}_{\mathrm{o}}$ \\
\hline $\begin{array}{l}\text { Breusch-Godfrey } \\
\text { Correlation LM Test }\end{array}$ & 0.7727 & 0.4476 & $\mathrm{H}_{\mathrm{o}}$ : Correctly specified & Cannot reject $\mathrm{H}_{\mathrm{o}}$ \\
\hline Ramsey RESET test & 4.6326 & 0.0986 & $\mathrm{H}_{\mathrm{o}}$ : Normal distribution & Cannot reject $\mathrm{H}_{\mathrm{o}}$ \\
\hline Jarque-Bera normality test & 1.0565 & 0.4346 & $\mathrm{H}_{\mathrm{o}}$ : Homoscedasticity & Cannot reject $\mathrm{H}_{\mathrm{o}}$ \\
\hline $\begin{array}{l}\text { Heteroskedasticity Test: ARCH } \\
\text { Country: Chad }\end{array}$ & 0.1592 & 0.0026 & $\mathrm{H}_{\mathrm{o}}$ : No serial correlation & Cannot reject $\mathrm{H}_{\mathrm{o}}$ \\
\hline $\begin{array}{l}\text { Breusch-Godfrey } \\
\text { Correlation LM Test }\end{array}$ & 0.7553 & 0.4584 & $\mathrm{H}_{\mathrm{o}}$ : Correctly specified & Cannot reject $\mathrm{H}_{\circ}$ \\
\hline Ramsey RESET test & 0.1859 & 0.9113 & $\mathrm{H}_{\mathrm{o}}$ : Normal distribution & Cannot reject $\mathrm{H}_{\mathrm{o}}$ \\
\hline Jarque-Bera normality test & 1.4169 & 0.2307 & $\mathrm{H}_{\mathrm{o}}$ : Homoscedasticity & Cannot reject $\mathrm{H}_{\mathrm{o}}$ \\
\hline Heteroskedasticity Test: ARCH
\end{tabular}

Table 3 revealed the diagnostic tests results for the ARDL model. The diagnostic test for Nigeria showed that the model specification was adequate and had a good fit. The results revealed that the ARDL model passed all the diagnostic tests. The ARDL model specified for the Republic of Chad passed all the diagnostic tests except the Breuch Godfrey Lagrange Multiplier (LM) test for serial correlation. However, there was presence of serial correlation in the ARDL model due to the significance of the F-statistic. Under the Ramsey Regression Equation Specification Error Test (RESET) test, the null hypothesis for linearity or correct specification was accepted due to the non-statistical significance of the f-statistic and t-statistic. Under the normality test, a Jarque-Bera value of 0.1859 which was less than 5.99 showed that the errors were normally distributed. Again, the non-significance of the Jarque-Bera statistic confirmed it. It resulted in the acceptance of the null hypothesis of normal distribution. Under the ARCH test, the null hypothesis of homoscedasticity was accepted as a result of a probability value of 0.2307 .

\subsection{Results of the Bounds Test for Cointegration}

The results of the Bounds tests for the presence of cointegration were shown in Table 4. The calculated $F$ statistic for the combined test of the parameters in the empirical design for the Republic of Chad was 7.0852. This F-statistic exceeds the upper critical value bounds at 1\%, 5\% and 10\% critical values. Based on this, the null hypothesis of no cointegration was rejected. Hence, on the basis of this result, a long-run relationship exist among the variables. However, the obtained F-statistic (3.8201) in Nigeria's empirical design is between the lower critical value bound $I(O)$ and the upper critical value bound $I(1)$. Hence, the test was inconclusive. Therefore, the 
inconclusive outcome means that long-run and short-run models may be considered. The presence of a long-run link among the variables in these models supported the estimation of the short-run dynamic and long-run coefficients using the ARDL method.

Table-4. Bounds Tests for the existence of cointegration

\begin{tabular}{|c|c|c|c|c|c|}
\hline \multicolumn{6}{|c|}{ Country: Nigeria } \\
\hline Test Statistic & Value & Lag & Significance Level & \multicolumn{2}{|c|}{ Bound Critical Values* Lower Bound Upper Bound } \\
\hline \multirow[t]{4}{*}{$F$-statistic } & 3.8201 & 2 & & $\mathrm{I}(\mathrm{O})$ & $\mathrm{I}(1)$ \\
\hline & & & $1 \%$ & 5.17 & 6.36 \\
\hline & & & $5 \%$ & 4.01 & 5.07 \\
\hline & & & $10 \%$ & 3.47 & 4.45 \\
\hline \multicolumn{6}{|l|}{ Country: Chad } \\
\hline \multirow[t]{4}{*}{$F$-statistic } & 7.0852 & 2 & & $\mathrm{I}(\mathrm{O})$ & $\mathrm{I}(1)$ \\
\hline & & & $1 \%$ & 5.17 & 6.36 \\
\hline & & & $5 \%$ & 4.01 & 5.07 \\
\hline & & & $10 \%$ & 3.47 & 4.45 \\
\hline
\end{tabular}

\subsection{Results of the Long-run Relationship}

Table-5. Results for estimated long-run coefficients.

\begin{tabular}{|c|c|c|c|c|}
\hline \multicolumn{5}{|c|}{ Dependent Variable: Log(RGDPPC) } \\
\hline \multicolumn{5}{|c|}{ Country: Nigeria } \\
\hline Variable & Coefficient & Std. Error & t-Statistic & Prob. \\
\hline $\mathrm{C}$ & 8.842870 & 1.272876 & $6.947158^{* * * *}$ & 0.0000 \\
\hline GFCF & -0.034514 & 0.024418 & -1.413424 & 0.1704 \\
\hline MILEXP & 0.271693 & 0.305219 & 0.890158 & 0.3822 \\
\hline TOPEN & -0.002892 & 0.006278 & -0.460646 & 0.6492 \\
\hline \multicolumn{5}{|c|}{ Country: Chad } \\
\hline $\mathrm{C}$ & 5.590213 & 0.157538 & $35.484884^{*} * *$ & 0.0000 \\
\hline GFCF & 0.001133 & 0.007661 & 0.147881 & 0.8838 \\
\hline MILEXP & 0.055174 & 0.019293 & $2.859723 * * *$ & 0.0091 \\
\hline TOPEN & 0.009813 & 0.004467 & $2.196969^{* *}$ & 0.0389 \\
\hline
\end{tabular}

Table 5 depicts the estimated long-run results of the link between military outlay and economic growth. For Nigeria, gross fixed capital formation had a negative and insignificant relationship with economic growth contrary to expectation. The unfavourable investment climate in Nigeria is one of the likely reasons for this result. This finding contravenes the submissions of Duru and Ehidiamhen (2018) but agrees with the finding of Duru, Okafor, Adikwu, and Njoku (2020) and Duru and Ezenwe (2020). In addition, military outlay exerted a positive relationship with economic growth. However, it was not significant. This means that a unit increase in military outlay would result in a 0.27 per cent increase in economic growth. The non-significance of the military outlay variable may not be unrelated with the mismanagement and diversion of some of the military funds by military officials. This result contravenes the findings of Deger (1986); Deger and Somnath (1995); Dunne et al. (2002); Dunne (2010); Dunne (2012); Dunne and Tian (2015); Feeny (2005) and Arshad et al. (2017).

However, the finding conforms to the results of the studies of Benoit (1978); Tiwari and Shahbaz (2011); Chairil et al. (2013); Apanisile and Okunlola (2014); Ajmair et al. (2018). Furthermore, openness to trade had a negative relationship with economic growth. This suggests that a unit increase in trade openness would reduce economic growth by 0.003 per cent. This indicates that trade openness does not encourage economic growth in Nigeria. One of the probable reasons for this may be the unfavourable investment climate in some parts of the country caused by insecurity. Another factor is the export of mainly primary products. This result corresponds with the suggestions of Rigobon and Rodrik (2005); Rodriguez and Rodrik (1999); Adhikary (2011); Bibi, Ahmad, and Rashid (2014); Qazi (2015); Olasode, Raji, Adedoyin, and Ademola (2015); Musila and Yiheyis (2015); Moyo, Nwabisa, and Hlalefang (2017); Moyo and Khobai (2018); Tyopev (2019); Duru et al. (2020) and Duru and Ezenwe (2020). However, the finding contravenes the suggestions of Nduka (2013); Olufemi (2004); Winters (2004); Sakyi (2011); Dao (2014); Ali and Abdullah (2015); Dabel (2016); Keho (2017); Yakubu and Akanegbu (2018); Elijah and Musa (2019) and Ajayi and Araoye (2019).

In the case of the Republic of Chad, gross fixed capital formation exerted a positive and insignificant relationship with economic growth as expected. This implies that investment contributes to economic growth in Chad. This implies that a unit increase in investment would result in a 0.001 per cent increase in economic growth. This finding contravenes the submissions of Duru and Ezenwe (2020) and Duru et al. (2020) but finds an advocate in Duru and Ehidiamhen (2018). In addition, military outlay had a positive and significant relationship with economic growth. This implies that a unit increase in military outlay would result in a 0.06 per cent increase in economic growth. The result finds an advocate in Anfofum (2011). Furthermore, openness to trade had a positive and significant relationship with economic growth as expected. This means that a unit increase in trade openness would increase economic growth by 0.01 per cent. This indicates that trade openness promotes economic growth in Chad. This finding disagrees with the submissions of Rigobon and Rodrik (2005); Rodriguez and Rodrik (1999); Adhikary (2011); Bibi et al. (2014); Qazi (2015); Olasode et al. (2015); Musila and Yiheyis (2015); Moyo et al. (2017); Moyo and Khobai (2018); Tyopev (2019); Duru et al. (2020) and Duru and Ezenwe (2020). However, the result corresponds with the suggestions of Nduka (2013); Olufemi (2004); Winters (2004); Sakyi (2011); Dao (2014); Ali and Abdullah (2015); Dabel (2016); Keho (2017); Yakubu and Akanegbu (2018); Elijah and Musa (2019) and Ajayi and Araoye (2019). 
Table-6. Results of estimated short-run error correction model

\begin{tabular}{|c|c|c|c|c|}
\hline \multicolumn{5}{|c|}{ Dependent Variable: Log(RGDPPC) } \\
\hline \multicolumn{5}{|l|}{ Country: Nigeria } \\
\hline Variable & Coefficient & Std. Error & t-Statistic & Prob. \\
\hline D(LOGRGDPPC(-1)) & 0.337379 & 0.198269 & $1.701622^{*}$ & 0.1017 \\
\hline $\mathrm{D}(\mathrm{GFCF})$ & -0.004418 & 0.001613 & $-2.738142^{* * * *}$ & 0.0115 \\
\hline $\mathrm{D}(\mathrm{GFCF}(-1))$ & 0.002012 & 0.001666 & 1.207548 & 0.2390 \\
\hline D(MILEXP) & 0.001713 & 0.043600 & 0.039292 & 0.9690 \\
\hline $\mathrm{D}(\mathrm{MILEXP}(-1))$ & -0.013759 & 0.034303 & -0.401105 & 0.6919 \\
\hline $\mathrm{D}(\mathrm{TOPEN})$ & -0.000343 & 0.000909 & -0.376903 & 0.7096 \\
\hline $\mathrm{D}(\mathrm{TOPEN}(-1))$ & 0.001528 & 0.000839 & $1.821647^{*}$ & 0.0810 \\
\hline $\mathrm{ECM}_{\mathrm{t}-1}$ & -0.135031 & 0.069106 & $-1.953971^{*}$ & 0.0625 \\
\hline \multicolumn{5}{|c|}{$\mathrm{ECM}=\mathrm{LOG}(\mathrm{RGDPPC})-0.0345^{*} \mathrm{GFCF}+0.2717^{*} \mathrm{MILEXP}-0.0029^{*} \mathrm{TOPEN}+8.8429 * \mathrm{C}-0.0142^{*} \mathrm{D}$} \\
\hline \multicolumn{5}{|l|}{ Country: Chad } \\
\hline D(LOGRGDPPC(-1)) & -0.146104 & 0.183191 & -0.797550 & 0.4337 \\
\hline $\mathrm{D}(\mathrm{GFCF})$ & 0.000429 & 0.002953 & 0.145259 & 0.8858 \\
\hline $\mathrm{D}(\mathrm{GFCF}(-1))$ & -0.004188 & 0.002554 & -1.639888 & 0.1153 \\
\hline D(MILEXP) & -0.007707 & 0.012817 & -0.601300 & 0.5538 \\
\hline $\mathrm{D}(\operatorname{MILEXP}(-1))$ & -0.015610 & 0.011996 & -1.301262 & 0.2066 \\
\hline $\mathrm{D}$ (TOPEN) & 0.000316 & 0.001427 & 0.221514 & 0.8267 \\
\hline $\mathrm{D}(\mathrm{TOPEN}(-1))$ & -0.002109 & 0.001560 & -1.351632 & 0.1902 \\
\hline $\mathrm{ECM}_{\mathrm{t}-1}$ & -0.430863 & 0.159071 & -2.708629 *** & 0.0128 \\
\hline
\end{tabular}

Note: ***,** and $*$ denote significance at $1 \%, 5 \%$ and $10 \%$ levels respectively.

The results of the short-run dynamic estimates are shown in Table 6. In the case of Nigeria, the short-run dynamic estimates to a great extent agree with the long-run estimates. Change in the log of real GDP had a positive and significant impact on economic growth in the first lag. On the other hand, gross fixed capital formation of the previous one year had a negative and significant link with economic growth. Change in military outlay exerted a positive and insignificant impact on real GDP in the short-run. This finding suggests that military outlay contributes to growth in the short-run in Nigeria.

This implies that economic growth would increase by 0.002 per cent, should military outlay be increased by one unit. Change in trade openness exerted a negative and insignificant effect on economic growth in the short-run. The coefficient of $\mathrm{ECM}_{\mathrm{t}-1}$, which is $14 \%$ implies that $14 \%$ of the previous deviation in economic growth from equilibrium is corrected by it within one year. The significance of the coefficient of the error correction term lagged by one period is an indication of long-run causality. Furthermore, the negative sign and significance of the coefficient of the error correction term to long-run stable equilibrium further corroborates the existence of a longrun nexus between real GDP and the explanatory variables.

However, for the Republic of Chad, change in the log of real GDP exerted a negative and insignificant impact on economic growth. The change in gross fixed capital formation had a positive and insignificant impact on economic growth in line with the long-run result. The change in military outlay had a negative and insignificant relationship with economic growth in the short run. The result means that if military outlay goes up by one unit, economic growth would decrease by 0.008 per cent. However, the change in trade openness had a positive and insignificant relationship with economic growth. The coefficient of $\mathrm{ECM}_{\mathrm{t}-1}$, which is $43 \%$ implies that $43 \%$ of the previous deviation in economic growth from equilibrium is corrected by it within one year. The significance of the coefficient of the error correction term lagged by one period is an indication of long-run causality. Furthermore, the negative sign and high significance of the coefficient of the error correction term to long-run stable equilibrium further corroborates the existence of a long-run nexus between real GDP and the explanatory variables.

\subsection{Results of Toda and Yamamoto Multivariate Causality Test}

Table-7. Results of the granger causality test (TY augmented lags methods).

\begin{tabular}{l|c|c}
\hline Country: Nigeria & \multicolumn{2}{|c}{ Sources of Causation } \\
\hline Dependent/ Variable & LOGRGDPPC $\chi^{2}$ & MILEXP $\chi^{2}$ \\
\hline MILEXP & 2.3415 & - \\
\hline LOGRGDPPC & - & 3.4432 \\
\hline Note: ****** and * indicate significance at the $1 \%, 5 \%$ and $10 \%$ respectively.
\end{tabular}

Table-8. Results of the granger causality test (TY Augmented lags methods).

\begin{tabular}{l|c|c}
\hline Country: Chad & \multicolumn{2}{|c}{ Sources of Causation } \\
\hline Dependent/ Variable & LOGRGDPPC $\chi^{2}$ & MILEXP $\chi^{2}$ \\
\hline MILEXP & 3.0432 & - \\
\hline LOGRGDPPC & - & 3.2626 \\
\hline Note: ***, ** and * indicate significance at the $1 \%, 5 \%$ and $10 \%$ respectively.
\end{tabular}

Toda and Yamamoto (TY) estimation results for Nigeria and the Republic of Chad is depicted in Table 7 and Table 8 respectively. The results in Table 7 revealed presence of no causality between real GDP per capita and military outlay for Nigeria. This finding suggests that there is no causal relationship between real GDP per capita and military outlay in Nigeria. In the case of Chad, the findings in Table 8 showed the existence of no causality 
between real GDP per capita and military outlay. This result suggests that there is no causal relationship between real GDP per capita and military outlay in Chad. The implications of these findings for Nigeria and Chad is that they can pursue the policy objectives of defence and economic growth independently. These results contravene those of Chowdhury (1991); Dunne and Vougas (1999); Dakurah et al. (2001); Kollias, Naxakis, and Zarangas (2004); Lai, Huang, and Yang (2005); Tiwari and Shahbaz (2011).

\section{Conclusion and Recommendations}

The empirical link between military expenditures and economic growth has been a very controversial issue in both developing and developed economies resulting in mixed results. Hence, this study contributed in a novel manner to the prevailing literature on military expenditures and economic growth by investigating the nexus between military outlay and economic growth in the Lake Chad Basin Countries with emphasis on Nigeria and the Republic of Chad using 1981-2019 and 1983-2019 respectively as ranges of data. The findings showed that military outlay contributes to economic growth in Nigeria. However, the non-significance of the military outlay variable may not be unrelated with the mismanagement and diversion of some of the funds meant for the military by military officials. On the other hand, military outlay exerted a positive and significant relationship with economic growth in the Republic of Chad. This implies that the resources allocated for the purpose of defence in the Republic of Chad is yielding the desired results. The Toda Yamamoto Multivariate Causality analysis showed no causal relationship between military outlay and economic growth in Nigeria and Chad respectively.

This results means that Nigeria and Chad can pursue the policy objectives of defence and economic growth independently. Based on the discoveries of this study, the following recommendations are proffered: The policymakers of the governments of both countries should pursue the policy objectives of defence and economic growth independently. The government of Nigeria should ensure that the investment climate in place is conducive for the attraction of investments and flourishing of individual businesses. The Nigerian government should provide more credit facilities to investors at reduced interest rate with a view to restoring their confidence in the economy. The use of military funds in Nigeria could be enhanced by fighting corruption. Hence, the Economic and Financial Crimes Commission (EFCC) and Independent Corrupt Practices and other Related Offences Commission (ICPC), charged with the responsibility of fighting corruption should rise to the occasion and track down military officials that divert defence funds for individual gains. The existing policies for promotion of trade in the Republic of Chad should be sustained. Furthermore, the government of Nigeria should implement proper fiscal and monetary measures through its right agencies to support trade.

\section{References}

Abu-Bader, S., \& Abu-Qarn, A. S. (2003). Government expenditures, military spending and economic growth: Causality evidence from Egypt, Israel, and Syria. Journal of Policy Modeling, 25(6-7), 567-583. Available at: https://doi.org/10.1016/s0161-8938(03)000577.

Adams, F. G., Behrman, J. R., \& Boldin, M. (1991). Government expenditures, defense, and economic growth in the LDCs: A revised perspective. Conflict Management and Peace Science, 11(2), 19-35. Available at: https://doi.org/10.1177/073889429101100202.

Adhikary, B. K. (2011). FDI, trade openness, capital formation, and economic growth in Bangladesh: A linkage analysis. International Journal of Business and Management, 6(1), 16-28.

Aizenman, J., \& Glick, R. (2006). Military expenditure, threats, and growth. Journal of International Trade \& Economic Development, 15(2), 129155.

Ajayi, E., \& Araoye, F. (2019). Trade openness and economic growth in Nigeria. International Journal of Economics and Financial Management, $4(2), 50-63$.

Ajmair, M., Hussain, K., Abbassi, F. A., \& Gohar, M. (2018). The impact of military expenditures on economic growth of Pakistan. Applied Economics and Finance, 5(2), 41-48. Available at: https://doi.org/10.11114/aef.v5i2.2932.

Alexander, W. R. J. (1990). The impact of defence spending on economic growth: A multi-sectoral approach to defence spending and economic growth with evidence from developed economies. Defence and Peace Economics, 2(1), 39-55. Available at: https://doi.org/10.1080/10430719008404677.

Ali, W., \& Abdullah, A. (2015). The impact of trade openness on the economic growth of Pakistan: 1980-2010. Global Business and Management Research: An International Journal, 7(2), 120-129.

Alptekin, A., \& Levine, P. (2012). Military expenditure and economic growth: A meta-analysis. European Journal of Political Economy, 28(4), 636-650.

Ando, S. (2008). The impact of defense expenditure on the economic growth: Panel data analysis based on the Feder model. Graduate School of Commerce, Meiji University, Tokyo, Japan.

Anfofum, A. A. (2011). The impact of defence expenditure on economic growth in Nigeria, 1970 - 2008: A simulation approach. An Unpublished Ph.D Economics of the Faculty of Social Sciences, Ahmadu Bello University, Zaria, Kaduna State, Nigeria.

Apanisile, T. O., \& Okunlola, C. O. (2014). Does military expenditure influence economic growth in Nigeria during 1989-2013? A bound testing approach. Romanian Journal of Fiscal Policy (RJFP), 5(2), 56-71.

Arshad, A., Syed, S. H., \& Shabbir, G. (2017). Military expenditure and economic growth: A panel data analysis. Forman Journal of Economic Studies, $13(1-12), 161-175$.

Atesoglu, H. S., \& Mueller, M. J. (1990). Defence spending and economic growth. Defence and Peace Economics, 2(1), 19-27. Available at: https://doi.org/10.1080/104307 19008404675.

Babin, N. (1986). The impact of military expenditures on economic growth and development in the less developed countries. PhD Dissertation, College Park, University of Maryland.

Benoit, E. (1973). Defense and economic growth in developing countries. Lexington, MA: Lexington Books.

Benoit., E. (1978). Growth and defense in developing countries. Economic Development and Cultural Change, 26(2), 271-280. Available at: https://doi.org/10.1086/451015.

Bibi, S., Ahmad, S. T., \& Rashid, H. (2014). Impact of trade openness, FDI, exchange rate and inflation on economic growth: A case study of Pakistan. International Journal of Accounting and Financial Reporting, 4(2), 236-257.

Biswas, B. (1993). Defense spending and economic growth. In LCDs: In J.E. Payne \& A.P. Sahu (Eds.), Defense Spending and Economic Growth. Boulder, CO: Westview Press.

Biswas, B., \& Ram, R. (1986). Military expenditures and economic growth in less developed countries: An augmented model and further evidence. Economic Development and Cultural Change, 34(2), 361-372. Available at: https://doi.org/10.1086/451533.

Bose, N., Haque, E., \& Osborn, D. (2003). Public expenditure and economic growth: A disaggregated analysis for developing countries. Retrieved from http://www.socialsciences.manchester.ac.uk/cgbcr/dpcgbcr/dpcgbcr30.pdf.

Brasoveanu, L. O. (2010). The impact of defense expenditure on economic growth. Romanian Journal of Economic Forecasting, 13(4), $148-168$.

Candar, O. (2003). Military expenditures and economic growth in Turkey. An Unpublished Master Thesis in Business Administration of the Department of Management, Institute of Economics and Social Sciences, Bilkent University, Ankara. 
Cetin, I., \& Guzel, S. (2019). Military expenditures and economic growth in Middle East and North African countries. Turkish Journal of TESAM Academy, 6(1), 187-211.

Chairil, T., Sinaga, D., \& Febrianti, A. (2013). Relationship between military expenditure and economic growth in ASEAN: Evidence from Indonesia. Journal of ASEAN Studies, 1(2), 106-121.

Chowdhury, A. R. (1991). A causal analysis of defense spending and economic growth. Journal of Conflict Resolution, 35(1), $80-97$.

Coloumb, F. (2004). Economic theories of peace and war. London: Routledge.

Coulomb, F., \& Bellais, R. (2008). The marxist analysis of war and military expenditures, between certainty and uncertainty. Defence and Peace Economics, 19(5), 351-359. Available at: https://doi:10.1080/10242690802354345.

Dabel, I. (2016). Trade openness and economic growth: Evidence from Ghana. An Unpublished Master of Philosophy Degree in Economics of the University of Cape Coast.

Dakurah, A. H., Davies, S. P., \& Sampath, R. K. (2001). Defense spending and economic growth in developing countries: A causality analysis. Journal of Policy Modelling, 23(6), 651-658. Available at: https://doi.org/10.1016/So161-8938(01)00079-5.

Dao, A. (2014). Trade openness and economic growth. Mark A. Israel'91 endowed summer research fund in economics. Retrieved from: https://digitalcommons.iwu.edu/israel_economics/2.

Deger, S. (1986). Economic development and defense expenditure. Economic Development and Cultural Change, 35(1), 179-196. Available at: https://doi.org/10.1086/451577.

Deger, S., \& Smith, R. (1983). Military expenditure and growth in less developed countries. Journal of Conflict Resolution, 27(2), 335-353. Available at: https://doi.org/10.1177/0022002783027002006.

Deger, S., \& Somnath, S. (1995). Military expenditures and third world countries. Ed. In K.Hartley \& T. Sandler (Eds.), Handbook of Defense Economics. BV Amsterdam: Elseiver Science.

DeRouen, J. K. R. (1994). Defense spending and economic growth in Latin America: The externalities effects. International Interactions, 19(3), 193-2 12. Available at: https://doi.org/10.1080/03050629408434827.

Dumas, J. (2002). The role of demilitarization in promoting democracy and prosperity in Africa. In J. Brauer \& J. Dunne (Eds.), Arming the South (pp. 15-33). London: Palgrave.

Dunne, J. P. (2010). Military spending and economic growth in Sub Saharan Africa. Preliminary draft. Retrieved from https://www.researchgate.net/publication/228816200.

Dunne, J. P., Nikolaidou, E., \& Smith, R. (2002). Military spending, investment and economic growth in small industrialising economies. South African Journal of Economics, 7O(5), 789-808. Available at: https://doi:10.1111/j.1813-6982.2002.tbo0045.x.

Dunne, J. P., Smith, R. P., \& Willenbockel, D. (2005). Models of military expenditure and growth: A critical review. Defence and Peace Economics, 16(6), 449-461. Available at: https://doi:10.1080/10242690500167791.

Dunne, J. P., \& Uye, M. (2010). Military spending and development. The global arms trade. London: Routledge.

Dunne, J. P., \& Tian, N. (2013). Military expenditure and economic growth: A survey. The Economics of Peace and Security Journal, 8(1), 5-11. Available at: https://doi:10.15355/epsj.8.1.5.

Dunne, J. P., \& Tian, N. (2015). Military expenditure, economic growth and heterogeneity. Defence and Peace Economics, 26(1), 15-31. Available at: https://doi:10.1080/10242694.2013.848575.

Dunne, J. P. (2012). Military spending, growth, development and conflict. Defence and Peace Economics, 23(6), 549-557. Available at: https://doi.org/10.1080/10242694.2012.663576.

Dunne, P., \& Coulomb, F. (2008). Peace war and international security: Economic theories. In J. Fontanel \& M. Chatterji (Eds.), War peace and security (pp. 13-36). Bingley: Emerald Group Publishing Limited.

Dunne, P. (1990). The political economy of military expenditure: An introduction. Cambridge Journal of Economics, 14(4), 395-404. Available at: https://doi.org/10.1093/oxfordjournals.cje.a035142.

Dunne, P., \& Vougas, D. (1999). Military spending and economic growth in South Africa: A causal analysis. Jouranl of Conflict Resolution, 43(4), 52 1-537. Available at: https://doi.org/10.1177/0022002799043004006.

Duru, I. U., \& Ehidiamhen, P. O. (2018). Empirical investigation of the impact of export diversification on economic growth: Evidence from Nigeria, 1980-2016. Journal of Economics, Management and Trade, 21(7), 1-24. Available at: https://doi.org/10.9734/jemt/2018/42806.

Duru, I. U., Okafor, B. O., Adikwu, F. O., \& Njoku, F. C. (2020). Trade liberalization and economic growth: An assessment of Nigerian experience. Asian Development Policy Review, 8(3), 194-2 13. Available at: https://doi.org/10.18488/journal.107.2020.83.194.2 13.

Duru, I. U., \& Ezenwe, U. (2020). Empirical investigation of the impact of exports on economic growth: Evidence from Nigeria, $1980-2016$. International Journal of Publication and Social Studies, 5(1), 18-43.

Elijah, S., \& Musa, A. B. (2019). Dynamic impact of trade openness on the economic growth in Nigeria. International Journal of Engineering and Advanced Technology, 8(5C), 609-616. Available at: https://doi.org/10.35940/ijeat.e1087.0585c19.

Faini, R., Annez, P., \& Taylor, L. (1984). Defense spending, economic structure, and growth: Evidence among countries and over time. Economic Development and Cultural Change, 32(3), 487-498. Available at: https://doi.org/10.1086/451402.

Feder, G. (1983). On exports and economic growth. Journal of Development Economics, 12(1-2), 59-73.

Feder, G. (1986). Growth in semi-industrial countries: A statistical analysis. In H. Chenery, S. Robinson \& M. Syrquin (Eds.), Industrialization and Growth: A Comparative Study (pp. 263-282). New York: Oxford University Press.

Feeny, S. (2005). The impact of foreign aid on economic growth in Papua New Guinea. Journal of Development Studies, 41(6), 1092-1117. Available at: https://doi.org/10.1080/00220380500155403.

Frederiksen, P., \& McNab, R. (2001). The relationship between defence spending and economic growth: A granger causality analysis for Malaysia, 1961 to 1999. STRATEGI. Journal of Strategic Studies on International Relations, 9(1), 63-71.

Galvin, H. (2003). The impact of defence spending on the economic growth of developing countries: A cross-section study. Defence and Peace Economics, 14(1), 51-59. Available at: https://doi.org/10.1080/10242690302932.

Gerace, M. P. (2002). US military expenditures and economic growth: Some evidence from spectral methods. Defence and Peace Economics, 13(1), 1-11. Available at: https://doi.org/10.1080/10242690210966.

Guaresma, J., \& Reitschuler, G. (2003). Guns or butter? Revisited: Robustness and nonlinearity issues in the defense-growth nexus. Working Paper No: 0310, Department of Economics, University of Vienna.

Gyimah-Brempong, K. (1989). Defense spending and economic growth in Subsaharan Africa: An econometric investigation. Journal of Peace Research, 26(1), 79-90. Available at: https://doi.org/10.1177/0022343389026001008.

Habibullah, M. S., Law, S. H., \& Dayang-Afizzah, A. M. (2008). Defense spending and economic growth in Asian economies: A panel errorcorrection approach. Munich Personal RePEc Archive, MPRA Paper No. 12105.

Halicioglu, F. (2004). Defense spending and economic growth in Turkey: An empirical application of new macroeconomic theory. Review of Middle East Economics and Finance, 2(3), 34-43. Available at: https://doi.org/10.2202/1475-3693.1028.

Haseeb, M. (2014). Defence expenditure and economic growth: A case study of Pakistan. An Unpublished Master of Economics Thesis of Othman Yeop Abdullah Graduate School of Business, Utara Malaysia University.

Hassan, M. K., Waheeduzzaman, M., \& Rahman, A. (2003). Defense expenditure and economic growth in the SAARC countries. The Journal of Social, Political, and Economic Studies, 28(3), 275-293.

Heo, U. (1996). The political economy of defense spending in South Korea. Journal of Peace Research, 33(4), 483-490. Available at: https://doi.org/10.1177/0022343396033004008.

Heo, U. (1998). Modeling the defense-growth relationship around the globe. Journal of Conflict Resolution, 42(5), 637-657. Available at: https://doi.org/10.1177/0022002798042005006.

Heo, U. (2010). The relationship between defense spending and economic growth in the United States. Political Research Quarterly, 63(4), 760770. Available at: https://doi.org/10.1177/1065912909334427.

Hou, N. (2010). Arms race, military expenditure and economic growth in India. Ph.D. Thesis, Department of Economics, The University of Birmingham.

Hou, N., \& Chen, B. (2013). Military expenditure and economic growth in developing countries: Evidence from system GMM estimates. Defence and Peace Economics, 24(3), 183-193. Available at: https://doi.org/10.1080/10242694.2012.710813. 
Huang, C., \& Mintz, A. (1990). Ridge regression analysis of the defence-growth tradeoff in the United States. Defence and Peace Economics, 2(1), 29-37. Available at: https://doi.org/10.1080/10430719008404676.

Huang., C., \& Mintz, A. (1991). Defence expenditures and economic growth: The externality effect. Defence and Peace Economics, 3(1), 35-40. Available at: https://doi.org/10.1080/10430719108404713.

Iftikhar ul Husnain, M., \& Shaheen, F. (2011). Defense expenditure-growth nexus: Empirical evidence from selected South Asian countries. Interdisciplinary Journal of Contemporary Research in Business 3(4), 163-171.

Karagol, E., \& Palaz, S. (2004). Does defence expenditure deter economic growth in Turkey? A cointegration analysis. Defence and Peace Economics, 15(3), 289-298. Available at: https://doi.org/10.1080/10242690320001608908.

Keho, Y. (2017). The impact of trade openness on economic growth: The case of Cote d'Ivoire. Cogent Economics Eீ Finance, 5(1), 1-14. Available at: http://dx.doi.org/10.1080/23322039.2017.1332820.

Kennedy, G. (1983). Defense economics. New York: St. Matins Press.

Kentor, J., \& Kick, E. (2008). Bringing the military back in. Journal of World-Systems Research, 14(2), 142-172.

Kinsella, D. (1990). Defence spending and economic performance in the United States: A causal analysis. Defence and Peace Economics, 1(4), 295-309. Available at: https://doi.org/10.1080/10430719008404669.

Klein, T. (2004). Military expenditure and economic growth: Peru 1970-1996. Defense and Peace Economics, 15(3), 275-288. Available at: http://dx.doi.org/10.1080/102426903200035101.

Kollias, C. (1994). Is there a Greek-Turkish arms race? The view from Athens. Cyprus Journal of Economics, 7(1), 52-62.

Kollias, C. (1995). Country survey VII: Military spending in Greece. Defence and Peace Economics, 6(4), 305-319. Available at: https://doi.org/10.1080/10430719508404834.

Kollias, C., \& Makrydakis, S. (1997). Is there a Greek-Turkish arms race?: Evidence from cointegration and causality tests. Defence and Peace Economics, 8(4), 355-379. Available at: https://doi.org/10.1080/10430719708404886.

Kollias, C., Naxakis, C., \& Zarangas, L. (2004). Defence spending and growth in cyprus: A causal analysis. Defence and Peace Economics, 15(3), 299-307. Available at: https://doi.org/10.1080/1024269032000166864.

Lai, C. N., Huang, B. N., \& Yang, C. W. (2005). Defense spending and economic growth across the Taiwan straits: A threshold regression model. Defence and Peace Economics, 16(1), 45-57. Available at: https://doi.org/10.1080/1024269052000323542.

Lim, D. (1983). Another look at growth and defense in less developed countries. Economic development and cultural change, $31(2), 377-384$. Available at: https://doi.org/10.1086/451326.

Looney, R. E. (1988a). Third-world military expenditure and arms production. London: Palgrave Macmillan.

Looney, R. E. (1988b). Military expenditures and socio-economic development in Africa: A summary of recent empirical research. The Journal of Modern African Studies, 26(2), 319-325. Available at: https://doi.org/10.1017/s0022278x00010491.

Looney, R. E., \& Frederiksen, P. C. (1986b). Defense expenditures, external public debt and growth in developing countries. Journal of Peace Research, 23(4), 329-338.

Luca, P. (2007). Military spending and economic growth. Working Papers No. 0708, Department of Accounting, Economics and Finance, Bristol Business School, University of the West of England, Bristol.

Maingi, J. N. (2010). The impact of government expenditure on economic growth in Kenya: 1963-2008. An Unpublished Doctor of Philosophy Degree in Economics Thesis of Kenyatta University.

Mintz, A., \& Stevenson, R. T. (1995). Defense expenditures, economic growth, and the "peace dividend": A longitudinal analysis of 103 countries. Journal of Conflict Resolution, 39(2), 283-305. Available at: https://doi:10.1177/0022002795039002004.

Mordi, C. N. O., Englama, A., \& Adebusuyi, B. S. (2010). The changing structure of the Nigerian economy (2nd ed.). Lagos, Nigeria: Atisele Vanessa Cards Co.

Moyo, C., Nwabisa, K., \& Hlalefang, K. (2017). The relationship between trade openness and economic growth: The case of Ghana and Nigeria. MPRA Paper No. 81317.

Moyo, C., \& Khobai, H. (2018). Trade openness and economic growth in SADC countries. MPRA Paper No. 84254.

Mueller, M. J., \& Atesoglu, H. S. (1993). Defense spending, technological change, and economic growth in the United States. Defence and Peace Economics, 4(3), 259-269. Available at: https://doi.org/10.1080/10430719308404765.

Musila, J. W., \& Yiheyis, Z. (2015). The impact of trade openness on growth: The case of Kenya. Journal of Policy Modeling, 37(2), 342-354. Available at: https://doi.org/10.1016/j.jpolmod.2014.12.001.

Mylonidis, N. (2008). Revisiting the nexus between military spending and growth in the European Union. Defence and Peace Economics, 19(4), 265-272. Available at: https://doi.org/10.1080/10242690802164801.

Narayan, P. K., \& Singh, B. (2007). Modelling the relationship between defense spending and economic growth for the Fiji Islands. Defence and Peace Economics, 18(4), 391-401. Available at: https://doi.org/10.1080/10242690600807924.

Nduka, E. K. (2013). Openness and economic growth in Nigeria. Journal of Education and Practice, 4(1), 68-73.

Nikolaidou, E. K. (1999). Defence spending and economic growth: A case study of Greece and comparison with Spain and Portugal (1960-1996). PhD Thesis, Middlesex University.

Ocal, N. (2002). Asymmetric effects of military expenditure between Turkey and Greece. Defence and Peace Economics, 13(5), 405-416. Available at: https://doi.org/10.1080/10242690213511.

Olasode, S., Raji, O., Adedoyin, O., \& Ademola, I. (2015). Trade openness and economic growth a reflection from Nigeria (1981-2012). International Journal of Economics, Commerce and Management, 3(5), 1-820.

Olufemi, S. M. (2004). Trade openness and economic growth in Nigeria: Further evidence on the causality issue. South African Journal of Economic and Management Sciences, 7(2), 299-315. Available at: https://doi.org/10.4102/sajems.v7i2.1375.

Osborn, D., Cutter, A., \& Ullah, F. (2015). Universal sustainable development goals: Understanding the transformational challenge for developed countries. Report of a Study by Stakeholder Forum.

Park, K. Y. (1993). Pouring new wine into fresh wineskins: Defense spending and economic growth in LDCs with application to South Korea. Journal of Peace Research, 30(1), 79-93. Available at: https://doi.org/10.1177/0022343393030001007.

Payne, J. E., \& Ross, K. L. (1992). Defense spending and the macroeconomy. Defence and Peace Economics, 3(2), 161-168. Available at: https://doi.org/10.1080/10430719208404724.

Pesaran, M. H., Shin, Y., \& Smith, R. J. (2001). Bounds testing approaches to the analysis of level relationships. Journal of Applied Econometrics, 16(3), 289-326. Available at: https://doi.org/10.1002/jae.616.

Qazi, M. A. H. (2015). Impact of economic liberalization on economic growth in the case of Pakistan. An Unpublished Doctor of Philosophy Degree of the Faculty of Economics and Administration, University of Malaya, Kuala Lumpur, Malaysia.

Raju, M. H., \& Ahmed, Z. (2019). Effect of military expenditure on economic growth: Evidences from India Pakistan and China using cointegration and causality analysis. Asian Journal of German and European Studies, 4(3), 1-8. Available at: https://doi.org/10.1186/s40856-019-0040-6.

Ram, R. (1986). Government size and economic growth: A new framework and some evidence from cross-section and time-series data. American Economic Review, 76(1), 191-203.

Ram, R. (1995). Defense expenditure and economic growth. In K. Hartley \& T. Sandler (Eds.), Handbook of Defense Economics (pp. 251273). Amsterdam: Elsevier.

Rigobon, R., \& Rodrik, D. (2005). Rule of law, democracy, openness, and income: Estimating the interrelationships 1. Economics of Transition, 13(3), 533-564. Available at: https://doi.org/10.1111/j.1468-0351.2005.00226.x.

Rodriguez, F., \& Rodrik, D. (1999). Trade policy and economic growth: A sceptic's guide to the cross-national evidence. NBER Macroeconomics Annual 2000, 15(1), 261-338.

Saba, C. S., \& Ngepah, N. (2019). Military expenditure and economic growth: Evidence from a heterogeneous panel of African countries. Economic Research, 32(1), 3586-3606. Available at: https://doi:10.1080/1331677X.2019.1674179.

Sakyi, D. (2011). Trade openness, foreign aid and economic growth in post-liberalisation Ghana: An application of ARDL bounds test. Journal of Economics and International Finance, 3(3), 146-156.

Sezgin, S., \& Yildirim, J. (2002). The demand for Turkish defence expenditure. Defence and Peace Economics, 13(2), 121-128. Available at: https://doi.org/10.1080/10242690210973. 
Shahbaz, M., Afza, T., \& Shabbir, M. S. (2013). Does defence spending impede economic growth? Cointegration and causality analysis for Pakistan. Defence and Peace Economics, 24(2), 105-120. Available at: https://doi:10.1080/10242694.2012.723159.

Smith, R. (1994). Measuring the effects of military spending: Cross sections or time series? In M. Chatterji, H. Jager, \& A. Rima (Eds.), The economics of international security (pp. 232-244). London: Palgrave Macmillan.

Smith, J. S., \& Tuttle, M. (2008). Does defense spending really promote aggregate output in the United States? Defence and Peace Economics, 19(6), 435-447. Available at: https://doi.org/10.1080/10242690701701950.

Smith, R. P. (1977). Military expenditure and capitalism. Cambridge Journal of Economics, 1(1), 61-76.

Stewart, D. B. (1991). Economic growth and the defense burden in Africa and Latin America: Simulations from a dynamic model. Economic Development and Cultural Change, 40(1), 189-207. Available at: https://doi.org/10.1086/451930.

Tekeoglu, E. (2008). Defence expenditures and economic growth: Empirical study on case of Turkey. An Unpublished Master of Business Administration Thesis from the Naval Postgraduate School, Monterey, California.

Tiwari, A. K., \& Shahbaz, M. (2011). Does defence spending stimulate economic growth in india? MPRA Paper No. 30880.

Tyopev, I. (2019). Trade openness and economic growth in selected West African countries. An Unpublished PhD Economics thesis of Benue State University, Makurdi, Benue State, Nigeria.

Ward, M. D., Davis, D., Penubarti, M., Rajmaira, S., \& Cochran, M. (1991). Country survey I-military spending in India. Defence and Peace Economics, 3(1), 41-63. Available at: https://doi.org/10.1080/10430719108404714.

Ward, M. D., \& Davis, D. R. (1992). Sizing up the peace dividend: Economic growth and military spending in the United States, $1948-1996$. American Political Science Review, 86(3), 748-755. Available at: https://doi.org/10.2307/1964136.

Weede, E. (1983). Military participation ratios, human capital formation, and economic growth: A cross national analysis. Journal of Political and Military Sociology, $11(1), 11-19$.

Wilkins, N. (2004). Defense expenditure and economic growth: Evidence from a panel of 85 countries. School of Finance and Economics, University of Technology, Sydney. Retrieved from: http://cama.anu.edu.au/macroworkshop/Nigel\%20Wilkins.pdf.

Winters, L. A. (2004). Trade liberalisation and economic performance: An overview. The Economic Journal, 114(493), F4-F21. Available at: https://doi.org/10.1111/j.0013-0133.2004.00185.x.

World Bank, \& UNHCR. (2016). Forced displacement by the Boko haram conflict in the Lake Chad Region. Geneva and Washington: The UNHCR and The World Bank Group.

Yakubu, M. M., \& Akanegbu, B. N. (2018). Trade openness and economic growth: Evidence from Nigeria. European Journal of Business, Economics and Accountancy, 6(4), 30-44.

Yildirim, J., Sezgin, S., \& Öcal, N. (2005). Military expenditure and economic growth in Middle Eastern countries: A dynamic panel data analysis. Defence and Peace Economics, 16(4), 283-295. Available at: https://doi.org/10.1080/10242690500114751. 